\title{
Ocorrência de Salmonella spp. em Carcaças de Frango Resfriadas no Período de 2000 A 2010
}

\author{
Ana Lúcia Sicchiroli Paschoal Cardoso (I), Eliana Neire Castiglioni \\ Tessari (I), Greice Filomena Zanatta Stoppa (I), Ana Maria Iba \\ Kanashiro (I), Renato Luis Luciano (I), Antonio Guilherme Machado \\ de Castro (I) \\ (I) IB - Instituto Biológico (Rua Bezerra Paes, 2278)
}

\section{Resumo}

O gênero Salmonella é composto por diferentes sorovares, podendo acarretar tanto a salmonelose aviária quanto a humana, quando da ingestão de produtos avícolas contaminados, representando um grave problema de saúde pública. Os alimentos são considerados potenciais veiculadores de salmonelose, podendo se tornar uma ameaça à segurança alimentar e para a indústria avícola. A legislação nacional e internacional determina a ausência de qualquer Salmonella spp. em $25 \mathrm{~g}$ da amostra analisada, incluindo carne de aves e ovos. No período de 2000 a 2010, pesquisou-se a presença de Salmonella spp. em 604 carcaças de frango resfriadas de diferentes abatedouros comerciais do Estado de São Paulo. A metodologia utilizada foi a descrita pela portaria $\mathrm{n}^{\circ} 8$ de 23/01/95 do MAPA (BRASIL, 1995). As amostras positivas foram encaminhadas para tipificação do sorovar no setor de Enterobactérias da Fundação Oswaldo Cruz no Rio de Janeiro-RJ. No ano de 2000 foram analisadas 120 amostras de carcaças de frango e não foi isolado salmonela. Em 2002, 2004, 2006, 2007, 2009 e 2010 foram analisadas 68, 29, 89, 116, 88 e 94 amostras de carcaças de frango e verificou-se a positividade de $13(19,1 \%), 6(20,7 \%), 13(14,6 \%)$, $3(2,5 \%), 30(34,1 \%)$ e $24(25,5 \%)$, respectivamente. S. Enteritidis foi o sorovar prevalente, de um total de 84 amostras positivas 44 foram tipificadas como este sorovar, seguidos pelos sorovares S. Albany, S. 
Infantis, S. Agona, S. Tennessee, S. Hildelberg, Salmonella spp., S. Kentucky, S. enterica O:4,5, S. Montevideo e S. Newport isolou-se 14, 10, 5, 4, 3, 3, 2, 2, 1 e 1 amostras, respectivamente. Estudos estimam que existam 80,3 milhões de casos anuais de doenças de origem alimentar relacionada com Salmonella em todo o mundo e a S. Enteritidis tem sido considerado o sorovar mais comum em casos de infecções em seres humanos, sendo a maioria associada a produtos avícolas. Entretanto nota-se que nos últimos anos têm ocorrido alterações significativas na predominância de sorovares de Salmonella associados a aves comerciais e infecções em humanos.

Palavras-Chave: carcaças de frango, Salmonella spp., segurança alimentar Agência de Fomento: 